\title{
1. An introduction to fiduciary finance
}

\subsection{INTRODUCTION}

The investment industry has gained prominence as many governments in developed countries have shifted responsibility to individuals to provide for their own financial security in retirement. Resource-rich and developing nations have also directed wealth receipts into financial markets to mitigate the depletion of their resources and to address intergenerational burdens arising from ageing populations. Combined, these trends have created an immense pool of professionally managed investment capital seeking returns from global financial markets. At the end of 2008, a pensions and investments survey of the world's 500 largest money management firms estimated they were entrusted with $\$ 53.3$ trillion of client funds and International Financial Services London (IFSL) estimates the global funds management market is worth $\$ 61.6$ trillion, ${ }^{1}$ a figure exceeding the world's gross domestic product (GDP) (\$60.6 trillion). ${ }^{2}$

At their core, fiduciary institutions are collective investments governed to provide a specific investment proposition to consumers: they intermediate between savers in the real economy and the capital markets to achieve these economic bargains. A critically important feature of this intermediation function is that individual investment decision-making is surrendered to an independent party (usually a pension fund trustee, fund manager or financial advisor). Concomitantly, the fiduciary duties typically imposed upon promoters and managers of fiduciary products create markedly different customer-supplier relationships and attaching obligations compared to traditional financial products issued by deposit-taking institutions and insurers.

The entrusting of funds in the hands of investment professionals has given rise to stakeholders' expectations about the investment industry's function as both a gatekeeper of investment value, and as an effective agent for change in standards of corporate governance and ethics within investee firms. The growth of the industry and market events has brought incredulity about the value proposition of fiduciary products and closer scrutiny of the many economic agents operating within the industry.

Even before the formal capitulation of the global economy into recession 
in 2009, and well before signs of the global financial crisis emerged early in 2007, volatility in financial markets had accelerated considerably following decades of deregulation, unfettered capital flows and economic globalization. In the real economy, 'systemic problems' were observed over the preceding two decades of financial globalization. This pro-cyclical decision-making within banks and non-financial enterprises manifested as reckless lending practices, excessive risk-taking and the creation of asset price bubbles. Throughout this era, however, financial innovation had been the impetus for creating a more efficient global financial system and as an enabler of economic growth.

As in previous episodes of financial crisis, as dramatic losses are reported in the financial media, a familiar pattern of reactive regulation has emerged. First, financial and investment policies are investigated to develop answers as to why these investor losses have occurred. Second, people who have lost money seek the introduction of penalties for what is perceived to be criminal or reckless behavior. Third, new regulations are imposed to allay concerns that these losses will recur.

This pattern was exemplified in the late 1990s with the crisis in emerging markets, where hedge fund managers were pilloried for causing upheavals in currency, bond and equity markets. The $\$ 3.6$ billion bailout of Long Term Capital Management in September 1998 further reinforced the perceived dangers of free-ranging investment funds. The speculative activities of hedge funds, however, were hardly an anathema (and arguably essential) to the functioning of financial markets. Although pundits blamed hedge funds for stressing the financial system, these investment vehicles largely remained outside of regulatory purview, and subsequently experienced enormous growth in assets into the new millennium, especially as investors became disaffected with the herding behavior of more mainstream fund managers.

The genre of corporate governance scandals which followed in the early 2000s resulted in sweeping re-regulation and prescriptive standards for firms which did not address the root causes of these debacles: namely, fraud and poor judgment. ${ }^{3}$ Nonetheless, fiduciary institutions, especially pension funds, were placed under intense pressure by stakeholders to employ their economic ownership and voting powers to change corporate behavior and improve financial returns. Such socially and politically meritorious moves, however, have exposed misunderstandings about the commercial realities of so-called 'fiduciary capitalism.'

It is true that sub-prime lending and securitization precipitated the collapse of the US financial sector and caused the dramatic retrenchment in global economic growth and asset prices in financial markets. Again, procyclical (or market-chasing) financial policies resulted in transient security 
valuation paradigms within which investors' risk tolerances appeared to change until a sharp reassessment of risk premiums caused a collapse in asset valuations. The latest iteration of financial crisis provides an opportunity to understand how willing and sophisticated market participants (especially institutional investors) directly facilitated the financial innovations of credit derivatives and sub-prime loans, which had repackaged and transformed financial risks successfully until the markets turned. Whilst the traditional trading banks and investment banks sponsored (and in some cases also invested in) these financial innovations, increasingly it was a parallel financial system of fiduciary institutions, with pension funds and hedge funds at its epicenter, which supplied the risk capital to create these securities, and subsequently have joined governments in recapitalizing the global financial system. ${ }^{4}$

Therefore, before introducing regulatory changes to address the observed effects of financial crises, and to more accurately attribute underlying causes, it is essential to examine the characteristics of fiduciary institutions more closely. Although banking institutions engaged in reckless lending practices and adopted excessive leverage, there is now a realization that a fundamental and structural change occurred in the architecture of global finance, within which fiduciary institutions seemingly ignored risks and chased returns which arguably allowed the financial crisis to occur. The causes of this behavior should be addressed by exploring the food chain of distributors, gatekeepers and economic incentives residing within the fiduciary finance system. Unlike relatively opaque banking institutions and operating firms, scrutiny of fiduciary institutions is possible given their innate transparency: this industry after all aggregates cash savings and transacts in the capital markets to capture returns, rather than to create wealth per se.

This book is organized into three main parts. Part I provides a contextual setting for fiduciary finance and the recent crisis in financial markets. Chapter 2 explores the origins of fiduciary products and the investment business. It differentiates fiduciary investment vehicles from traditional financial institutions and provides details of their economic stature and interconnectedness with the global financial system. Chapter 3 explores investment in its commercial setting. It explains the range of constraints governing investment decision-making which can differ markedly from the 'textbook' depiction of investment management as a process dominated by valuation judgments and economic rationality.

Given the scale of assets entrusted to fund managers and the inextricable linkages existing between practice and theory, Part II explores the intellectual foundations of the investment discipline. Chapter 4 surveys the extant literature of the investment discipline to assess its scope and scientific status. Chapter 5 provides a critique of the measurement 
methodology used within academic and practitioner spheres to assess the merits of human judgment in investment management (colloquially, the 'active versus passive debate'). Far from being a settled science, this debate has profound implications for how money is invested and the governance of investee firms.

Part III of the book explores major topical developments affecting the investment industry, and considers the role of collective investment funds in the financial markets, and the regulatory landscape that has emerged since the financial markets meltdown.

Chapter 6 examines the role and influence of the gatekeepers of fiduciary finance: investment consultants. These agents exert significant influence over the allocation of capital to players within the fiduciary finance industry. This chapter uses a unique study of their activities within Australia's pension funds segment, one of the world's most sophisticated. This study assists in explaining why the industry's relative performance fixation may supplant fundamental valuation measures in decision-making.

Chapter 7 examines the rise of state-controlled sovereign wealth funds (SWFs). The sheer scale and growth of assets in this emergent, but operationally opaque segment of fiduciary finance has raised concerns about the motivations and investment practices of these vehicles which have played a highly visible role during the recent financial crisis.

In light of the heightened expectations that collective investments can be mobilized as effective agents for change in corporate sustainability and environment concerns, Chapter 8 examines the topical area of sustainable investments, a diverse grouping of strategies incorporating non-financial criteria.

Finally, in light of the themes explored in the book, Chapter 9 considers the regulatory reforms which have been undertaken to enhance the stability of financial markets and provide better outcomes for the global environment and corporate governance. This chapter considers features of institutional investment operations and regulatory changes affecting financial markets, fiduciary product segments and risk-taking in broader financial institutions.

\subsection{FIDUCIARY FINANCE AND THE CAPITAL MARKETS}

At their core, fiduciary institutions are governed to provide a specific investment proposition to consumers and intermediate between savers in the real economy and the capital markets. As illustrated in Figure 1.1, although asset pricing is a visible function of financial markets, they can 

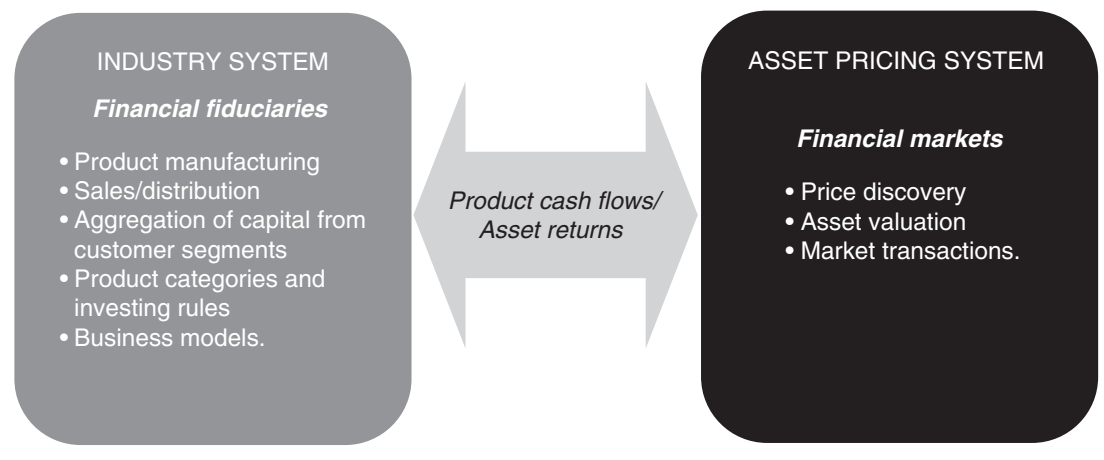

Figure 1.1 Fiduciary product flows and financial market transactions

be affected by the capital aggregation and transactional flows, which occur within the fiduciary finance industry. During episodes of financial crises large-scale funds flows induced by panic or speculative motivations within fiduciary product markets have directly affected asset pricing in financial markets. This reality was again demonstrated in the most recent crisis in financial markets.

The economic significance of fiduciary finance has previously been recognized as extending far beyond investment and portfolio management functions, into the real economy. Clarke (1981) characterizes its evolutionary development into four stages which have shaped the modern capitalist system: first, as the promoter, manager and investor it facilitated the formation of capital for entrepreneurial investments in the nascent economic enterprises and government sectors of the late nineteenth century; second, it hastened the rise of the business manager as the burgeoning popularity of public corporations resulted in the widespread separation of ownership and control; third, it created the specialized and professional function of the portfolio manager, which makes specific decisions regarding the deployment of investment capital, risks and liquidity; finally, in its ultimate manifestation as the savings planner, it interacts with individual savers to determine how capital should be supplied for investment purposes (and is central to the health of the entire economic system).

\subsection{DEFINING FIDUCIARY FINANCE}

Fiduciary finance can be defined broadly as a specialized commercial activity concerned with the provision of administration, advice and selection of investments and encompasses the following: 
- Provision of portfolio administration services (such as asset custody, account-keeping, cash-flow/liquidity management) and investment selections.

- Intermediated capital market exposure via commingled investment portfolios which do not usually create any direct beneficial entitlement to portfolio assets. ${ }^{5}$

- Provision of financial services with a commercial rationale/business imperative of achieving economies of scale and increased profit for the fiduciary.

- Operation of an investment strategy - a specified 'economic bargain' - effected by an investment specialist (such as a funds manager) via a contractual arrangement known as an 'investment mandate.'

- Separation of legal ownership and control of assets which creates a fiduciary relationship ${ }^{6}$ with specific obligations owed to clients (the ultimate beneficiaries) by the fiduciary product manager.

- Aggregation of funds from savings sectors into fiduciary products through the industry's tertiary market/economic sub-system (or 'food chain').

- Specialized knowledge and expertise with regard to wealth management and financial affairs generally.

From an investment perspective, and in comparison to investments made directly into financial markets, fiduciary products promise significant economic advantages, primarily derived from the scale efficiencies generated by pooling investors' capital:

- Dedicated professional management and access to specialized expertise.

- Efficient information collection and processing.

- Access to opportunities residing within global capital markets.

- Superior portfolio diversification.

- Lower trading costs.

- Simplified portfolio administration and reporting.

Pozen (2002) describes fiduciary products as a relatively pure 'passthrough' financial intermediary: they rarely promise repayment of the customer's original capital contributions, nor give a predetermined rate of return on that capital. Essentially, therefore, fiduciary products provide 'investment promises' which are fulfilled from an investment strategy outlined in product disclosure statements. The economic proposition of fiduciary finance contrasts markedly with the 'return promises' offered by 
Table 1.1 Financial products, promises and prudential regulation

\begin{tabular}{|c|c|c|c|}
\hline & \multicolumn{3}{|c|}{ Type of financial institution } \\
\hline & $\begin{array}{l}\text { Bank/authorized } \\
\text { deposit }\end{array}$ & Insurer & Financial fiduciary \\
\hline Product & $\begin{array}{l}\text { Current or term } \\
\text { deposit account }\end{array}$ & Insurance policy & $\begin{array}{l}\text { Fiduciary product } \\
\text { labeled according to } \\
\text { compliance regime: } \\
\text { that is, pension fund } \\
\text { or mutual fund }\end{array}$ \\
\hline Return promise & $\begin{array}{l}\text { Specified rate of } \\
\text { return (interest } \\
\text { rate) }\end{array}$ & $\begin{array}{l}\text { Returns contingent } \\
\text { on event; and/ } \\
\text { or investment } \\
\text { portfolio }\end{array}$ & $\begin{array}{l}\text { Returns from } \\
\text { specified investment } \\
\text { strategy }\end{array}$ \\
\hline $\begin{array}{l}\text { Liability structure } \\
\text { and management }\end{array}$ & $\begin{array}{l}\text { Financial } \\
\text { liabilities to } \\
\text { customers } \\
\text { recorded on } \\
\text { balance sheet }\end{array}$ & $\begin{array}{l}\text { Assets and } \\
\text { liabilities } \\
\text { segregated/ } \\
\text { hypothecated } \\
\text { but supported } \\
\text { by insurance } \\
\text { guarantee; } \\
\text { regulated portfolio }\end{array}$ & $\begin{array}{l}\text { Assets and } \\
\text { liabilities of product } \\
\text { segregated from } \\
\text { sponsor }\end{array}$ \\
\hline Regulatory regime & $\begin{array}{l}\text { Risk-adjusted } \\
\text { capital adequacy }\end{array}$ & Solvency & $\begin{array}{l}\text { Licensing of } \\
\text { financial advice } \\
\text { and investment } \\
\text { managers; product } \\
\text { disclosure }\end{array}$ \\
\hline $\begin{array}{l}\text { Recourse to } \\
\text { sponsor }\end{array}$ & $\begin{array}{l}\text { Depositors have } \\
\text { higher ranking } \\
\text { than owners/ } \\
\text { shareholders }\end{array}$ & $\begin{array}{l}\text { Policyholders } \\
\text { have priority } \\
\text { claim behind } \\
\text { other creditors but } \\
\text { higher ranking } \\
\text { than owners/ } \\
\text { shareholders }\end{array}$ & $\begin{array}{l}\text { No recourse to } \\
\text { capital of product } \\
\text { sponsor or } \\
\text { investment manager }\end{array}$ \\
\hline
\end{tabular}

traditional financial institutions and necessitates different structures and regulatory regimes (Table 1.1).

For example, banks and deposit-taking institutions make specific promises to depositors (independent of financial market returns, interest rates and economic risks); insurers make contingent return promises (returns are guaranteed but are contingent upon certain specified events such as the policyholder's economic loss, personal injury or death).

Banks and other deposit-taking institutions record their obligations to 
customers (liabilities) on their balance sheets and must manage any assetliability mismatches arising to ensure the specified returns are delivered. Similarly, insurers support their contingent return promises by segregating them into different pools of liabilities and hypothecate asset portfolios to manage any asset-liability mismatch (and thus maintain solvency). Insurers accept risks from their customers, however their promises are generally long term and can be quantified actuarially according to prior claims experience. In addition to customer premiums (which incorporate a margin on the capital supporting these products), insurers also generate investment returns which may be shared with policyholders. In contrast to other financial products, fiduciary products do not subject their sponsors and managers to any significant asset-liability mismatch: fund managers and product promoters do not normally employ their own capital resources to support portfolio returns. The assets and liabilities of investment funds are fully segregated from the fiduciary (see Box 1.1).

In Australia, trusts are the most common legal instrument interposed between the investors and the underlying investment portfolios for pension and managed funds. Under this structure, custodians hold legal title to the assets of the fiduciary product (on behalf of the ultimate beneficiaries) which provides an additional safeguard of investors' interests (Figure 1.2). Sponsors and promoters of fiduciary products are therefore obligated to operate the fund's stated investment strategy, and, importantly, fulfill the administrative/service standards, which comprise the "commercial bargain' outlined in the product disclosure documents.

\subsection{EVOLUTION OF THE FIDUCIARY MODEL OF INVESTING}

The predecessors of contemporary fiduciary products were closed-end investment trusts which emerged in Holland in 1774, Britain in 1868 and America in 1890. Hutson (2005) notes that the first true investment fund appeared in Britain in 1868 and the investment trust industry remained largely a British phenomenon until the development of open-ended mutual funds in the USA during the 1920s. Australia's first mutual fund, the Australian Foundation and Investment Corporation, was listed on the Australian Securities Exchange (ASX) in 1928. The evolution of fiduciary products has been accompanied by trends to 'un-bundle' investment exposure from insurance and other financial services, providing increased transparency in the investment strategies offered (Figure 1.3).

The predecessors of the contemporary 'pass-through' fiduciary products were guaranteed investment contracts (GICs) and insurance policies issued 


\section{BOX 1.1 PROTECTING INVESTORS: CAPITAL ADEQUACY IN THE FUNDS MANAGEMENT CONTEXT}

Because fund managers do not guarantee client balances, the bank model of capital adequacy is not relevant. Whilst maintaining adequate financial reserves should lessen the potential for business failure, capital per se plays a very small role in investor protection: it cannot provide protection against fraud, irregular dealing or negligence which may occur within the investment management process.

The risks faced by investors in funds management can be separated into two main categories: 'direct risks' which present the greatest potential for the loss of investors' capital, and 'indirect risks' which present only a minimal potential for direct losses of investors' entitlements (Table 1.2).

Table 1.2 Investor risk and protection measures

\begin{tabular}{ll}
\hline Risks category & Protection/risk mitigation measures \\
\hline $\begin{array}{l}\text { Direct } \\
\text { Fraud, theft and non-contractual } \\
\text { wealth transfers }\end{array}$ & Business insurance \\
$\begin{array}{l}\text { Commingling of client and } \\
\text { corporate assets }\end{array}$ & $\begin{array}{l}\text { Segregation of client and corporate } \\
\text { assets using independent trustee/ } \\
\text { custodians }\end{array}$ \\
$\begin{array}{l}\text { Risks within the investment } \\
\text { management processes ('front } \\
\text { office' or 'back office') }\end{array}$ & $\begin{array}{l}\text { Monitoring of business operations } \\
\text { by internal and external auditors; } \\
\text { regular 'middle office' compliance } \\
\text { reporting }\end{array}$ \\
$\begin{array}{l}\text { Indirect } \\
\text { Business failure }\end{array}$ & $\begin{array}{l}\text { Sufficient capital and liquidity to } \\
\text { allow forward coverage of operating } \\
\text { expenses }\end{array}$ \\
Bustemic/industry risks & Business continuity planning \\
\hline
\end{tabular}

The most prevalent risks (which are also difficult to detect) arise from irregular dealing of client assets. These events may be relatively mild (for example, a breach of portfolio exposure guidelines which creates unexpected return consequences) or 
severe (for example, misappropriation of client assets). The risks caused by fraud or contractual breaches are best mitigated with appropriate business insurance cover.

In most fiduciary products, an independent custodian (typically a bank or trustee company) holds the legal title to its assets and is responsible for providing safekeeping of those assets. This creates a structural separation between ownership (which resides with the custodian which is responsible for providing safekeeping of the investors' interests) and control of portfolio assets (which resides with the fund manager whose services are delegated to it according to an investment mandate). The risks inherent in both 'front office' (dealing) and 'back office' (recording and valuation of assets) necessitate regular surveillance of information systems and accounting processes. In most substantial firms, a 'middle office' function (which may be provided by the custodian) supports internal compliance needs, and, more importantly, provides timely performance reporting information for industry gatekeepers which monitor fund managers on behalf of pension fund trustees. Investment and accounting systems are subject to periodic audit and review.

Of the indirect risks, although the business failure of a fund manager would likely create considerable consternation amongst investors, this event should not expose any material risk to their capital because management rights are usually sold to another provider who then assumes responsibility for the portfolios (and charging clients). The critical issue is that the outgoing fund manager has adequate financial resources to ensure an orderly transition to the new provider occurs. Similarly, systemic and industry risks require adequate liquidity and management resources to ensure there is business continuity.

In summary, it is preferable that investment managers hold sufficient capital as a buffer for contingencies and for business continuity. Capital does not provide protection for the majority of risks faced by investors and the companies themselves, and excessive capital requirements can diminish the return on assets and potentially reduce industry competition.

by life insurance offices, trustee companies and friendly societies. GICs provide customers with specific and certain payoffs; most paid a lump sum to the holder at the end of a fixed term, or paid an annuity income stream for a specified period. These return promises were made under the 


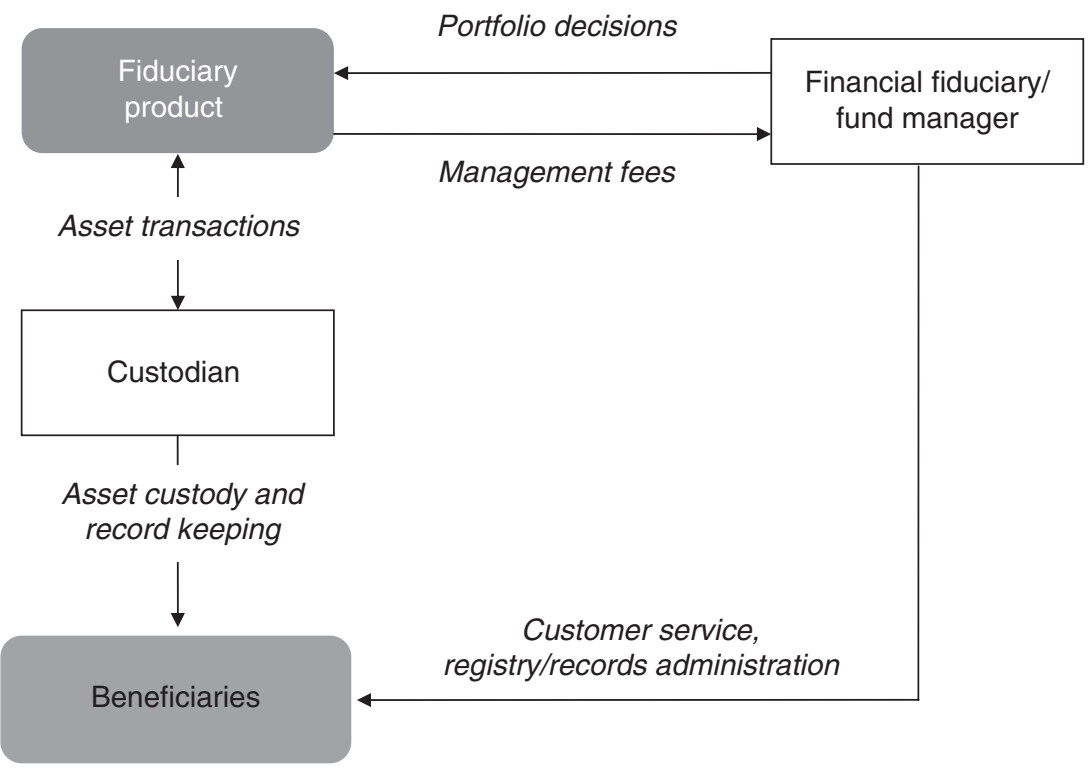

Source: Adapted from Ali et al. (2003).

Figure 1.2 Functional separation of the financial fiduciary and its products

umbrella of an insurance guarantee supported by a regulated asset portfolio. Purchasers of GICs were shielded from the volatility of financial markets: the investment portfolios which supported their return promises were opaque to the policyholder and there was no need to monitor the investment portfolios because the insurer ultimately guaranteed the product promises from reserves and its financial resources.

From the early 1980s, life insurers devised new types of contracts

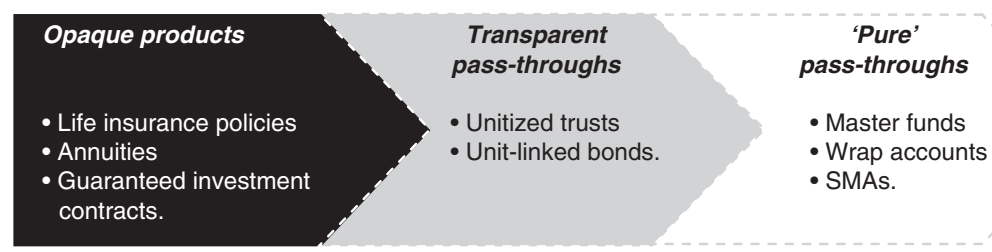

pre-1980s 1980s mid 1990s to current

Figure 1.3 Innovation and evolution of fiduciary products 
including 'capital guaranteed' investment bonds. A diversified, long-term investment portfolio backed these products and reserving techniques were employed whereby the full returns earned by the asset portfolio were not credited directly to customer accounts. Instead, the insurer 'smoothed' returns and part of the return earned on the asset portfolio was transferred to reserves supporting the capital guarantee (provided on initial contributions and/or the returns subsequently credited to the policyholder). Insurers also created 'unit-linked' bonds whose returns fluctuated according to the performance of their investment portfolios (in contrast to capital guaranteed policies). These insurance bonds were typically 'bundled' with term, death and disability insurances offered for additional premium contributions. These products usually imposed considerable surrender penalties for early termination for reasons of equity (to stop short-term trading in policies) and to protect the product's profitability.

The development of Australia's fiduciary finance industry has followed the trends of financial deregulation and product innovation witnessed offshore. Pozen (2002) notes that in the USA the product innovation of money market mutual funds was the genesis of the industry's subsequent growth. These fiduciary products offered investors higher returns than the interest-bearing accounts offered by banks without any up-front commissions and lower management fees than traditional stock and bond mutual funds. In December 1980, Hill Samuel Australia (now Macquarie Group) established the Hill Samuel Cash Management Trust (now Macquarie Cash Management Trust), which grew to be Australia's largest retail managed fund in 2006.

During the 1980s, several merchant banks (including Bankers Trust, County NatWest, Dominguez Barry Samuel Montagu, Hambros and Wardley) established specialized funds management businesses to cater to the emerging market for retirement and investment products, joining established trustee companies such as Perpetual Trustees, which had earlier established the Perpetual Industrial Share Fund in August 1966 catering to individuals and foundations. Trading banks and life insurance offices also began offering investment trusts distributed by non-affiliated financial advisors.

The latest iteration in fiduciary products, investment platforms (known as 'wrap accounts,' 'master funds, 'investor-directed portfolio services' and 'separately managed accounts'), provide a pure pass-through investment proposition: the operator maintains a 'menu' of approved investments and investors make selections often in consultation with a financial advisor. Investment platforms principally provide administration infrastructure for client portfolios and transactions, but do not undertake valuation judgments or investment selections. Importantly, whilst investment platforms are a pure pass-through investment conduit, they have supported rather 
than diminished financial intermediation overall, becoming the dominant source of new funds flows within the fiduciary finance industry.

\subsection{INDUSTRY SEGMENTS AND ECONOMIC STATURE}

Fiduciary products take numerous institutional forms including pension funds, hedge funds, mutual funds, money market accounts and investment contracts. Government policies have shaped the growth of the fiduciary finance industry by shifting responsibility for financial security in retirement onto individuals via pension privatization. More recently, many governments have established SWFs to invest national wealth receipts and these vehicles have joined the burgeoning assets of pension and retirement funds seeking returns from capital markets.

Estimating the economic stature of the fiduciary finance industry is problematic because unlike traditional financial institutions, no governing/ supervisory body routinely collects data across the industry's segments in global jurisdictions. There are also significant overlaps (cross-investments) which can occur between industry segments and data limitations are caused by varying levels of disclosure and quality (especially within hedge funds and SWFs). However, a comprehensive survey of the world's 500 largest money management funds found that they controlled over $\$ 53.3$ trillion of client funds at the end of 2008. To the extent that this data relies upon disclosures by wealth managers, it understates assets which are managed internally by governments or private organizations. The IFSL values the 'conventional' global funds management industry at $\$ 61.6$ trillion at the end of 2008 and estimates that the total 'private wealth' of individuals was $\$ 32.8$ trillion (of which approximately one third was held in pension funds, insurance funds and mutual funds (IFSL, 2009b)).

Overwhelmingly, pension funds are the dominant segment of fiduciary assets (Figure 1.4). According to the Organisation for Economic Cooperation and Development (OECD) estimates, private pension assets for its member countries were valued at \$22.4 trillion at the end of 2008 (down from $\$ 27.8$ trillion the previous year-end) equivalent to approximately 90 percent of $\mathrm{GDP}^{7}$ and more than 60 percent of private pensions were held in the USA. ${ }^{8}$ At the end of December 2008, the Investment Companies Institute (ICI) valued the US retirement system at $\$ 14.0$ trillion (down 22 percent from the previous year), with the largest component: individual retirement accounts (\$3.6 trillion); employer-sponsored defined contribution funds (\$3.5 trillion); federal, state and local government pension plans ( $\$ 3.5$ trillion). Public pension reserve funds established within the OECD and selected countries 


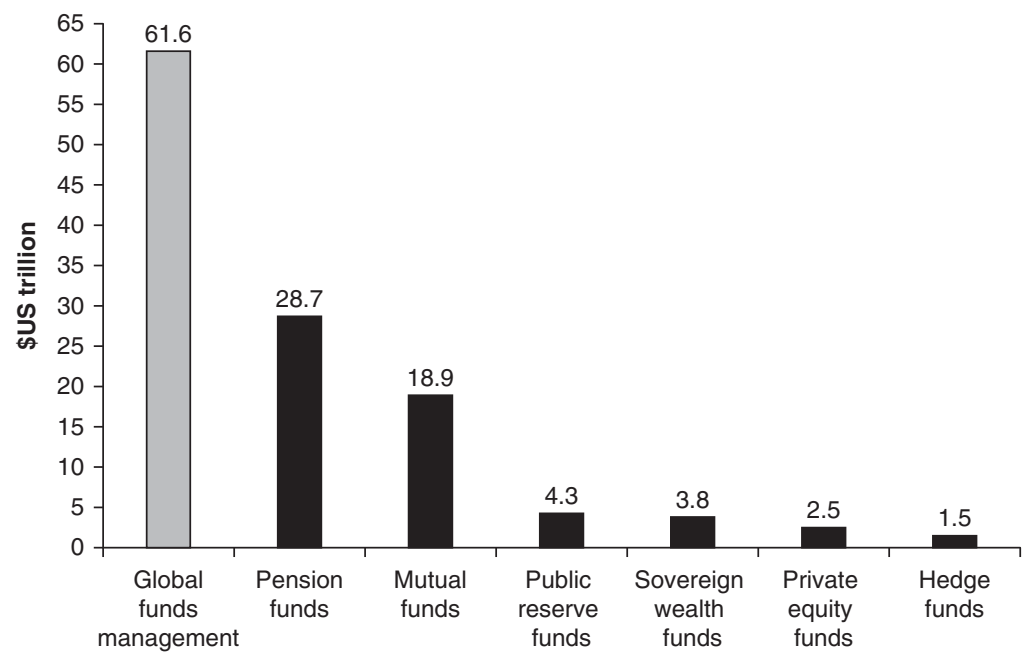

Source: IFSL, OECD, BIS, ICI, author's calculations.

\section{Figure 1.4 Global fiduciary finance system assets}

to support defined contribution (pay-as-you-go) public pension systems and social security spending were valued at over $\$ 4.3$ trillion.

Mutual funds, used by individual and institutional investors for discretionary savings, are the second largest segment of fiduciary assets. The value of global mutual funds at December 2008 year-end was \$18.9 trillion, a decline of $\$ 7.2$ trillion (27.4 percent) compared with the previous year. ${ }^{9}$ The USA is the world's largest mutual fund market with over $\$ 9.6$ trillion (51 percent of the global total) managed on behalf of 93 million investors following a decline of $\$ 2.4$ trillion (20 percent) compared with the previous year. ${ }^{10}$ Money market funds are the single largest fund category (40 percent) followed by domestic stock funds ( 30 percent), international stock funds (9 percent), bond funds (16 percent) and hybrid funds (5 percent) (ICI, 2009, pp. 20-21). Institutional investors own about 18 percent of mutual fund industry assets and non-financial firms were the largest category of investors holding $\$ 879$ billion ( $\$ 736$ billion held in money market funds) (ibid., p. 3).

SWFs have emerged as a heterogeneous institutional grouping of fiduciary finance assets: typically they are managed to generate returns from foreign currency reserves and fiscal surpluses (see Chapter 7). The SWF segment is valued at more than $\$ 3$ trillion, and these investment vehicles have attracted increasing scrutiny from governments, regulators and market analysts. Unlike mainstream fiduciary products, which are 


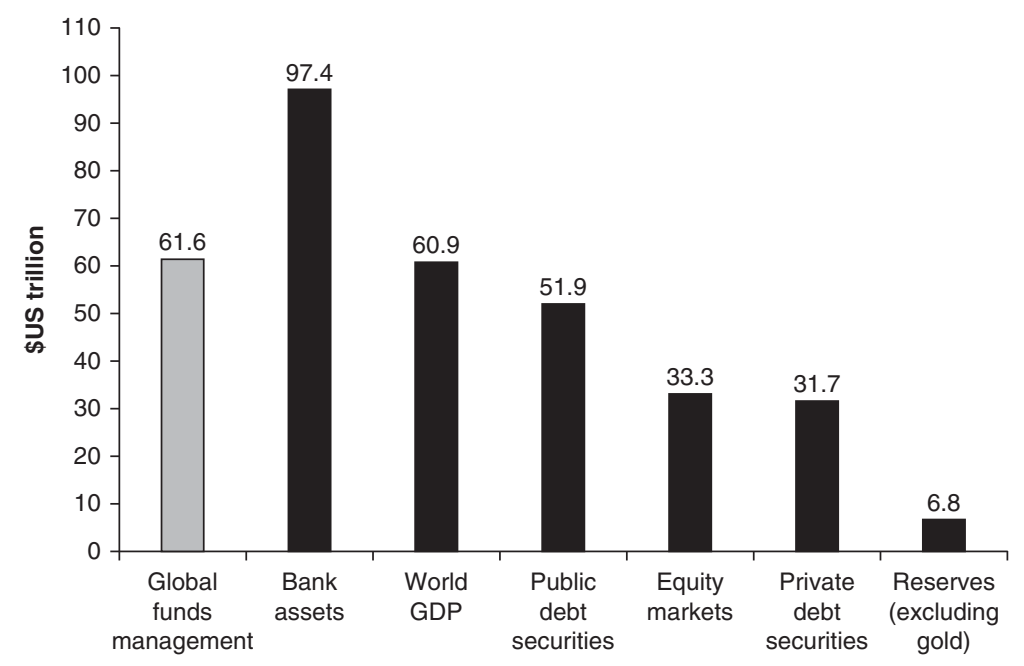

Source: IFSL, BIS, OECD, World Federation of Exchanges, author's calculations.

\section{Figure 1.5 Capital market and financial aggregates}

accountable to investors and follow clearly defined investment policies, SWFs are usually accountable only to their government sponsors (which in many cases are not democracies). Many SWFs have adopted investment governance structures and outsourced asset management to fund managers. There has been an inexorable rise in numbers of SWFs and their assets since the 1990s; however, until the financial crisis, their investing activities remained shrouded in secrecy. However, they became central players in providing capital to recapitalize global institutions and this has coincided with a determination of governments to allay market concerns about the investment operations of SWFs.

Hedge funds and private equity funds, which were recipients of increasing portfolio allocations from pension funds especially during the past decade, recorded strong growth before the crisis caused falling asset prices, negative returns and product outflows. According to the European Central Bank (ECB), unlevered capital under management in hedge funds totaled $\$ 1.2$ trillion at the end of December 2008. ${ }^{11}$ IFSL estimates that the value of hedge funds was $\$ 1.5$ trillion following a 30 percent decline in segment assets since 2007 (IFSL, 2009c, p. 1). By contrast, despite the falling valuations in public markets, private equity funds that captured large commitments from investors before the financial crisis recorded asset growth (of 15 percent) to an estimated $\$ 2.5$ trillion at the end of 2008 (ibid., p. 4).

The size of the global fiduciary finance industry can be put into context 
by a comparison with the traditional banking system, capital markets and financial aggregates (Figure 1.5). According to the International Monetary Fund (IMF), the value of global banking system assets was $\$ 97.4$ trillion at the end of December 2008. ${ }^{12}$ The Bank for International Settlements (BIS) estimates that the combined value of debt securities was $\$ 83.5$ trillion, and the World Federation of Exchanges records the total capitalization of global equity markets at $\$ 33.3$ trillion: a 46.9 percent decline from $\$ 62.7$ trillion the previous year. ${ }^{13}$

These data reveal that even in the aftermath of the significant falls in global financial markets, the assets of the fiduciary finance system rival traditional banking, insurance and savings institutions as a source of investment capital. The latent economic power of the fiduciary finance industry lies in the reality that most collective investment funds (hedge funds whose resident leverage from borrowing and derivative usage being the principle exception to this rule) are precluded from using economic leveraging to enlarge their assets, in direct contrast to traditional financial institutions and other members of the shadow banking system.

\subsection{INVESTMENT FUNDS AND THE MARKET MELTDOWN}

Many observers regard the bankruptcy of investment bank Lehman Brothers on 15 September 2008 as the defining event in the 'crashing' of the global financial system. However, this critical event was preceded and arguably precipitated elsewhere within the architecture of the global financial system: more specifically, within the hedge fund and money market segments which functioned in short-term credit markets alongside traditional financial institutions (trading and investment banks) and where illiquid bank assets were transformed into liquid, marketable securities through securitization.

In a speech he made in June 2008, US Treasury Secretary Timothy Geithner (then President and CEO of the New York Federal Reserve Bank) noted that the trio of hedge funds, money market funds and special purpose financing vehicles had grown to such an extent that they were systemically interconnected, via investment banks which were facilitating financial innovation, to represent a 'parallel banking system' whose assets eclipsed traditional banks (which remained subject to prudential regulation):

The structure of the financial system changed fundamentally during the boom, with dramatic growth in the share of assets outside the traditional banking system. This non-bank financial system grew to be very large, particularly in money and funding markets. In early 2007, asset-backed commercial paper conduits, in structured investment vehicles, in auction-rate preferred securities, 
tender option bonds and variable rate demand notes, had a combined asset size of roughly $\$ 2.2$ trillion. Assets financed overnight in triparty repo grew to $\$ 2.5$ trillion. Assets held in hedge funds grew to roughly $\$ 1.8$ trillion. The combined balance sheets of the then five major investment banks totaled $\$ 4$ trillion. In comparison, the total assets of the top five bank holding companies in the United States at that point were just over $\$ 6$ trillion, and total assets of the entire banking system were about $\$ 10$ trillion.

Whilst the growth and size of the parallel financial system was driven by its inherent leverage (a feature of accelerating asset prices and two preceding decades of moderate inflation outcomes and sustained economic growth), the interconnectedness between investment funds/alternative financing vehicles and traditional banking institutions was characterized by the 'liquidity bridge' which the former provided the latter. Hedge funds and money market funds which were the buyers of financial securitizations, well before their combined size rose to challenge traditional institutions, became a critical source of capital for balance sheet transformation and a dominant provider of short-term liquidity for the US financial system.

As real estate became a driver of US economic growth, taxation revenues and profits, the financial system became heavily dependent upon investment funds and the process of financial innovation, so much so that any shocks or disruptions to sub-prime markets would ultimately imperil the US financial (and thus, global) system and economy. Fiduciary institutions, which had operated beyond the reach of prudential oversight and banking regulations, experienced dramatic asset growth. The following sections examine the events occurring within segments of investment funds and the effects on financial system stability before and after the bankruptcy of Lehman Brothers. ${ }^{14}$

\subsubsection{Hedge Funds}

Hedge funds were highly active in sub-prime mortgage markets and the difficulties encountered by several high profile firms were early portents to the future crisis in credit and capital markets. On 3 May 2007, UBS announced the closure of its Dillon Read Capital Management hedge fund unit, which managed about $\$ 3.5$ billion of proprietary capital and about $\$ 1.2$ billion for external clients. Although its clients had made money, UBS closed the hedge fund unit after only 11 months of operation because it had incurred losses of \$124 million from sub-prime mortgage-backed securities. ${ }^{15}$

On 20 June 2007, the investment bank Bear Stearns announced that two of its hedge funds, the High-Grade Structured Credit Strategies Enhanced Leverage Fund and High-Grade Structured Credit Strategies Fund, established only ten months earlier to undertake leveraged bets 
on mortgage-backed securities and credit derivatives, faced serious difficulty. These funds raised approximately $\$ 1.56$ billion from investors and borrowed approximately $\$ 9$ billion (using collateralized debt obligations (CDO) as collateral for these loans) from the largest commercial and investment banks including Merrill Lynch, JP Morgan Chase, Citigroup, Deutsche Bank and Lehman Brothers to make bets on the sub-prime mortgages market.

On 17 July 2008, Bear Stearns revealed its hedge funds had lost more than 90 percent ( $\$ 1.4$ billion) of their original value: in March 2007 they had held $\$ 925$ million in investor capital and gross long positions of $\$ 9.7$ billion in sub-prime securities. ${ }^{16}$ On 19 June 2008, Lehman Brothers, one of the smaller lenders to the Bear Stearns hedge funds, seized and sold CDOs but reportedly received only 50 cents in the dollar. On 22 June 2008, Bear Stearns announced a bailout proposal for its hedge funds which would see it extend emergency loans of $\$ 3.2$ billion (approximately one quarter of the firm's capital) to prevent lenders from seizing assets and creating forced selling into depressed markets. Following this announcement, Merrill Lynch seized $\$ 825$ million of CDOs and attempted to recover its collateral, but abandoned the auction process when it realized only $\$ 100$ million from higher quality CDOs. ${ }^{17}$ Other lenders bypassed the open market and sold their securities back to Bear Stearns to quit their exposures. ${ }^{18}$

The auction's failure engendered a loss of confidence in the marketability and value of the circa $\$ 2.5$ trillion market of mortgage-backed securities and credit derivatives. For hedge funds which had been actively trading in sub-prime securities using leveraged positions, and more conventional money market and bond funds which sought yield enhancement from short-term debt, valuations become clouded and active trading in CDOs effectively stopped. Investment banks, in particular, which operated highly leveraged balance sheets (and in some cases also held significant proprietary positions in sub-prime markets) and depended heavily on money markets for day-to-day liquidity needs, were extremely vulnerable to any disruption and shocks to confidence.

The contagion from the sub-prime markets quickly radiated to the offshore credit markets. On 7 August 2007, BNP Paribas announced the temporary suspension of pricing and withdrawals for three of its funds, which had 'high quality' assets (that is, on average 90 percent of portfolio assets were invested in sub-prime securities rated AA or higher). The fund manager cited 'the sudden evaporation from 6 August of any trading activity on certain sectors of the US market' and the need 'to protect all investors and ensure that they received equal treatment during these exceptional circumstances. ${ }^{19}$ In Germany, WestLB Mellon Asset Management, Union Investment Asset Management and Frankfurt Trust also temporarily 
suspended product redemptions due to the disruptions in markets, even though they did not have any direct exposure to US sub-prime assets. On 29 August 2007, an Australian hedge fund manager, Basis Capital Fund Management, filed for bankruptcy protection. Its fund manager stated that it expected losses in its Basis Yield Alpha Fund would exceed 80 percent and it was unable to meet margin calls from counterparties, which had issued default notices and sought to seize the fund's assets.

On 17 March 2008, Bear Stearns, which had been Wall Street's fifth largest bank, was acquired by JP Morgan Chase in a deal brokered by the US Federal Reserve (which provided a non-recourse loan of $\$ 29$ billion) ${ }^{20}$ Ultimately, the demise of Bear Stearns was caused by concerns about its liquidity rather than a shortage of capital, and it was these concerns that had become self-fulfilling. ${ }^{21}$

In August, central banks (including the US Federal Reserve, ECB, Bank of England, Bank of Japan, Bank of Canada and Reserve Bank of Australia) introduced emergency measures to address a growing crisis in confidence and injected liquidity into credit markets. In the UK, mortgage lender Northern Rock, which had relied heavily upon US sub-prime credit markets for its funding, sought emergency assistance (and was ultimately nationalized) by the British government as it faced a run on deposits. HBOS and the Royal Bank of Scotland were also nationalized in November 2008.

\subsubsection{Money Market Funds}

The failure of Bear Stearns and Lehman Brothers' bankruptcy resulted in contagion being transmitted from the sub-prime category to prime credit markets, and it also starkly highlighted the systemic interconnectedness of the financial system with the previously uncontroversial segment of fiduciary institutions: money market mutual funds. Money market funds were created in the USA in 1971. At the end of 2008, the segment represented a $\$ 3.8$ trillion pool of short-term capital for operating companies and financial institutions where funds could be borrowed at lower interest rates than conventional bank facilities. ${ }^{22}$

Money market funds offer individuals and institutions all of the features of conventional regulated bank deposit accounts (including high liquidity, check access and a stable $\$ 1$ value) but with higher returns. Although subject to the US Securities and Exchange Commission (SEC) regulations (like other mutual funds), money market funds remained beyond the scope of the US Federal Reserve's prudential supervision, despite the reality that they represented a vital component of the US financial system, and a critical funding conduit for the US short-term credit markets. Money market funds hold 45 
percent of commercial paper, 65 percent of short-term state and local government debt, and 26 percent of short-term Treasury and agency securities. ${ }^{23}$

Money market funds, although operating at the lowest end of the credit risk spectrum, became central players in the US financial system following the bankruptcy of Lehman Brothers. This reinforced the pass-through nature of fiduciary investments: as investors sought to redeem their investments from money market funds and/or fund managers made provisions to meet these expected requests, this triggered upheaval in credit markets which required unprecedented intervention by the US government. This played out inside the Reserve Primary Fund, the nation's oldest and 18th largest money market fund, which held over $\$ 62$ billion prior to the Lehman Brothers collapse. Investors in the fund included large financial services groups (including Ameriprise, $\$ 3.2$ billion and Deutsche Bank, $\$ 500$ million) and a Chinese SWF (China Investment Corporation, \$5.3 billion).

The Reserve Primary Fund had a \$785 million (approximately 1.3 percent of its net asset value (NAV)) exposure to Lehman Brothers' debt and it paid out full redemptions (at a $\$ 1$ price) worth $\$ 10.8$ billion and issued receipts for another $\$ 28$ billion after the announcement of Lehman Brothers' bankruptcy. Because of the loss from these securities, the fund was forced to 'break the buck,' and announced its liquidation with remaining investors expected to receive only 97 cents in the dollar. ${ }^{24}$ On 18 September 2008, an institutional money market fund, the Putnam Prime Money Market Fund, with $\$ 14.4$ billion under management, announced its liquidation. The trustees stated that the closure of the fund (despite the fact that it did not have any exposure to Lehman Brothers or AIG) was necessary because it was unable to meet redemptions in the prevailing market conditions: the liquidation provided an orderly realization of its portfolio ensuring equitable treatment for all investors.

The breaking of the buck by the Reserve Primary Fund induced investor panic and over $\$ 230$ billion was withdrawn from the money market segment within three days of the Lehman Brothers event. Money market funds drastically reduced their holdings of even highly rated commercial paper (reportedly by $\$ 200$ billion or 29 percent of the total market) in the final two weeks of September 2008 to meet investor redemptions. Anticipating further redemptions, fund managers also shifted portfolio assets into Treasury securities. This precautionary activity pushed the cost of issuing commercial paper to its highest level in eight months and left many leading companies, banks and public institutions, which relied on the money markets to raise cash for operating expenses, effectively without financing.

The prospect of further forced selling by money market funds to meet investors' redemptions and the severe disruption in commercial paper and other short-term funding markets created a seizure that threatened the 
entire US financial system. On 18 September 2008, the US government announced that the US Treasury would guarantee investors' savings in money market funds (if the fund's NAV fell below $\$ 0.995$ per share). Money market funds with a combined value of $\$ 3$ trillion participated in the scheme and were required to pay up-front fees of between 1 and 1.5 basis points. This program expired on 18 September 2009 and earned the US government approximately $\$ 1.2$ billion in participation fees. Significantly, it brought money market funds into the broader toolkit of measures used by the authorities to manage financial liquidity and monetary policy. ${ }^{25}$ The US Federal Reserve also established the Asset-Backed Commercial Paper (ABCP) Money Market Mutual Fund Liquidity Facility (or 'AMLF') 'to assist money funds that held such paper in meeting demands for redemptions by investors and to foster liquidity in the ABCP market and money markets more generally.' This program provided a lending facility for US depository institutions and bank holding companies to purchase ABCP from the money market mutual funds. The program began operations on 22 September 2008 and closed on 1 February 2010. During its operation, up to $\$ 23.3$ billion was borrowed from the US Federal Reserve. ${ }^{26}$

The events occurring in the hedge fund and money market fund segments reveal the central role that these fiduciary institutions play in the global financial system. The parallel banking system, which had successfully facilitated credit creation for home ownership and risk transference, when faced with large-scale redemptions, imperiled the global financial system. Several hedge funds were early and highly visible examples of the sub-prime market meltdown because they had taken massively leveraged bets. Investment funds had aggregated capital from risk-seeking investors and sponsored the financial innovation of US sub-prime lending and mortgage origination in the USA. Since the onset of the global financial crisis in 2007, coordinated action by authorities has averted the collapse of the financial system. The combination of toxic loan support measures, central bank intervention in financial markets and fiscal stimulus has restored liquidity and normality but the ultimate cost to taxpayers is difficult to quantify. ${ }^{27}$ Importantly, there are few documented instances where investors in fiduciary products have suffered losses from fraud or impropriety.

\section{NOTES}

1. $\operatorname{IFSL}(2009 b)$.

2. Sourced from the World Development Indicators database, available at http://siteresources.worldbank.org/DATASTATISTICS/Resources/GDP.pdf (accessed 7 October 2009). 
3. Corporate governance standards were considered inadequate despite the reality that many failed firms had 'ticked the good corporate governance boxes.'

4. As noted in the International Organization of Securities Commissions' (IOSCO) final report on the sub-prime crisis, institutional investors had until relatively recently been excluded from investing in ABS because their mandates did not permit low credit ratings. The convergence of favorable conditions (rising property prices, low mortgage default rates and innovations in CDOs including yield enhancement and greater diversification) brought higher credit ratings for these securities. For further details, see: $\operatorname{IOSCO}(2008)$.

5. There are few exceptions to this. Institutional investors may effect their investments and redemptions in specie (in-kind) rather than cash transactions. Also, exchange-traded funds (ETFs) may permit in specie portfolio transactions.

6. Under this fiduciary relationship, the service provider is obliged to satisfy the terms of its commercial bargain with the customer, to act in the clients' best interest and exercise care when dealing with their funds at all times.

7. OECD (2009a) and IFSL (2009a).

8. OECD (2009b, p. 2).

9. Data extracted from ICI (2009, table 58).

10. Ibid.

11. See ECB (2009, chart S16, statistical annex S10).

12. Data source: IMF (2009b, table 3).

13. Data from Worldwide Federation of Exchanges website: http://www.world-exchanges. org/statistics/time-series/market-capitalization (accessed 12 December 2009).

14. For an excellent review of events from the perspective of the insurance industry, see Liedtke (2010).

15. UBS ultimately reported net losses of $\$ 18.7$ billion in relation to its US residential mortgage exposures for the year ended 31 December 2007 (disclosed in a formal report to shareholders (Shareholder Report on UBS's Write-Downs) published on 18 April 2008.

16. Federal prosecutors put former Bear hedge fund managers Ralph Cioffi and Matthew Tannin on trial alleging that they had misled investors; however, they were acquitted of criminal charges in November 2009. In December 2009, a Financial Industry Regulatory Authority (FINRA) arbitration panel reportedly awarded more than $\$ 3.4$ million to one investor that had placed $\$ 5$ million in the Bear Stearns hedge funds suggesting other investors may seek restitution from JP Morgan Chase.

17. The sub-prime market comprised CDOs based on a portfolio of resetting mortgage instruments, collateralized loan obligations (CLOs) used for financing takeovers, 'CDOs squared' which invested in other CDOs and so-called 'synthetic CDOs' (which comprised over one third of the entire CDO market) which had their returns linked according to the performance of other CDOs.

18. JP Morgan Chase, Bank of America and Goldman Sachs agreed not to sell assets on the open market.

19. BNP Paribas Investment Partners resumed calculation of the net asset values of the three funds.

20. As a result of the takeover, the US Federal Reserve acquired mortgages that were valued at $\$ 30$ billion in June 2008. A recent Financial Times report notes that these assets declined to \$27.1 billion at the end of 2009: H. Sender, 'Fed carries losses from Bear portfolio', FT.com, 15 February 2010.

21. On 20 March 2008 Christopher Cox, the Chairman of the US Securities and Exchange Commission (SEC), wrote to Dr Nout Wellink, Chairman of the Basel Committee on Banking Supervision, and notes that Bear Stearns had adequate capital: concerns about its solvency led to the denial of credit and counterparty withdrawals which caused its liquidity crisis and collapse. See http://www.sec.gov/news/press/2008/2008-48_letter.pdf (accessed 11 October 2009).

22. At the year-end of December 2008, $\$ 1356.8$ billion was invested in retail and $\$ 2475.5$ billion in institutional money market funds (ICI, 2009, table 38). 
23. These data are cited in a letter sent on 3 February 2010 to the editor of the Wall Street Journal, by ICI President Paul Stevens: 'Wall Street Journal v. the facts on money market funds', available at the ICI website, http://www.ici.org/pressroom/speeches/10 wsj_mmfs (accessed 2 March 2010).

24. In subsequent litigation brought by the SEC and investors, a US court ordered that remaining shareholders receive 98.75 percent of their investments in the fund: C. Condon, 'Ameriprise wins, Deutsche Bank loses in Reserve primary ruling', Bloomberg.com, 26 November 2009.

25. The US Federal Reserve is considering whether to allow money market funds to trade directly with it (rather than only via primary dealers) as it seeks to reduce $\$ 800$ billion of liquidity that the central bank pumped into the US financial system. C. Torres and C. Condon, 'Fed in talks with money market funds to help drain \$1 trillion', Bloomberg.com, 11 February 2010.

26. This peak was reached in May 2009 but usage of the facility ceased by the end of November 2009. Source: table 1a Aggregate Reserves of Depository Institutions and the Monetary Base, available at http://www.federalreserve.gov/ (accessed 12 February 2010).

27. For estimates of the value of crisis-related measures, see IMF (2009c, table 3) and OECD (2009c, table III.9). 